\title{
USING LIVEWORKSHEETS TO DIVERSIFY LANGUAGE LESSONS
}

\author{
Novikova Ye. B. ${ }^{1}$ \\ ${ }^{1}$ Kharkiv National Automobile and Highway University
}

\begin{abstract}
In the last decade a new up-to-date product an interactive book has been created. The essence of the interactive book has been revealed. The advantages of using interactive books, in particular Liveworksheets while teaching a language have been presented. The peculiarities of creating your own interactive workbooks by means of Liveworksheets platform have been shown. Main possibilities of using interactive workbooks at language lessons have been investigated. The ways of assessing students using Liveworksheets have been described.
\end{abstract}

Key words: interactive book, Liveworksheets, teaching language, worksheet creation.

\section{Introduction}

One of the important aspects of modern education is the mastery of cognitive universal educational activities: the ability to use observations to obtain information, conduct research to establish the characteristics of an object, formulate conclusions based on the results of an observation, classify and differentiate the objects under study following the content of a specific academic subject. As well as mastering the skills to participate in collaborative activities: the ability to determine the common goals of these activities and ways to achieve them, agree on distributing functions and roles, show a willingness to lead, evaluate their contribution to a common cause; and mastering the skills to work with information: to be able to choose sources for obtaining information, use various search methods (textbooks, digital electronic means, dictionaries of various types, reference sources in the open educational information space of the Internet), collecting, processing, analysing and transmitting information under the tasks of the subject.

In connection with the solution of these problems, teachers are looking for new approaches, ideas and methods of teaching to meet the modern requirements for education.

One of the ways to achieve this goal of education at this stage is to use one of the methods of interactive learning technology.

With the development of new information technologies of the third millennium, a new generation of people of the digital age was formed. They are mainly young people and children, the so-called "screen generation", who cannot imagine their life without technology and global network. Young people are more and more interested in modern high-tech devices, that distract them from meaningful and educa- tional reading. In the context of rigid communication between reading and computer games, a communication tool that combines these two types of leisure is necessary. The publishing market offers a new product, an interactive book that successfully combines information technology and content.

\section{Analysis of Publications}

For more than a decade, the publishing market offer consumers of electronic products various types of book production formats (audiobooks, multimedia books, etc.). In the last decade, the integration of information and publishing technologies has created a new modern product - an interactive book.

Many scientific papers of Ukrainian and foreign scholars are devoted to creating modern interactive books, in particular children ones [5, 9-11]. The comparison of paper and electronic books is presented in [13, 14]. Some scientists studied the peculiarities of interactive textbook creating [1-3, 6-7]. Advantages and disadvantages of using interactive textbooks are partially analysed in $[2,8,16]$. However, the possibilities of using interactive worksheets created at Liveworksheets platform have not been studied enough.

\section{Purpose and Tasks}

The purpose of the article is to reveal the essence and advantages of using interactive books, in particular Liveworksheets while teaching a language.

To achieve the aim, it is necessary to solve the following problems: to find out a common definition of the "interactive book" term, to analyse the existing platforms for their creating, to define the peculiarities of creating your own interactive workbooks, to give the examples of Liveworksheets workbooks. 


\section{Using Liveworksheets Platform at Language Lessons}

In recent years, the interest of teachers in such a unique means of enhancing the independent cognitive activity of students as an interactive worksheet has significantly increased. It is this didactic tool that provides effective feedback and promotes the implementation of the ideas of formative assessment.

"Interactive book" provides access to an alternative reality with the ability to interact with the main characters, actually existing through email, QR-codes, sites, etc.

An electronic or digital book designed to include active reader participation via links or embedded reader-enacted functions.

Analysing different definitions $[1,7,10,12]$, we can select the main properties of an interactive book: dynamism, clickability and multimedia, the plot of the book is not fixed rigidly, but can change depending on the choice of the reader. Thus, the interactive book emerged as a paper book with an alternative plot, and with the development and improvement of computers, especially personal, began to spread in the form of a kind of video games, especially text quests.

Technological innovations are part of English learning and teaching, but not all of them exist for a long time. The novelty of some innovations is deteriorating, and privacy and data protection is growing. Only innovations widely implemented in teaching practice will have long duration.

Nowadays there is different content for students, some programs allow them to create their own content and share it with others. Popular online sites such as Quizizz, Kahoot! and Socrative allow teachers and students to create online games and play games created by users from around the world. Sites like Canva allow teachers and students to express their creativity through posters, social media memes and banners. In addition, there are sites for creating memory cards, sites for creating comics and sites for editing / creating movies.

Creating content with such tools allows students to use language creatively and turn language practice into a fun and exciting activity.

Interactive learning is a practical approach that helps students become more interested and learn more material, strengthen their problemsolving and critical thinking skills.

Education process is constantly changing. Students are no longer required to sit at a desk and take notes in lectures. The lessons are much more interesting and interactive. Interactive learning is a practical, realistic approach to education. Interactive learning actively involves students in the struggle with the material. It enlivens the classroom for both students and teachers. Lectures turn into discussions, and students and teachers become partners in the process of acquiring knowledge.

As universities evolve and add new technology to the classroom, lessons also become more interesting for students. In mathematics, for example, there are hundreds of interactive programs for elementary and high school students. Usually students ask for more exciting technology-based classes, but this does not apply to math worksheets! Interactive historical events are available online for students studying history or social studies. In some activities, students are asked to participate and learn more about traveling to a new world. A variety of scientific activities are also available. Students can learn about astronomy, animals and the environment. In one interactive program, students imagine that they are inventors and invent something new.

Many interactive options are also available for language learning. For students with different level of English, there are many websites where they revise parts of speech, grammar or vocabulary. It's also easy to find word games such as executioners, crossword puzzles or verbal fights.

Smart boards, if they are available in the classroom, are a great tool that allows students to interact with the material and each other. A smart board is a large interactive whiteboard attached to a classroom wall that looks like a whiteboard. The main difference is that the whiteboard uses touch recognition to create a much more interactive lesson. Interactive lessons are always in touch for students or teachers.

If there is no possibility of using interactive textbooks, you may create your own interactive book using Liveworksheets platform [4].

Liveworksheets allows you to turn your traditional printed sheets (doc, pdf, jpg, etc.) into interactive online exercises with self-correction, called "interactive worksheets". Students can fill in worksheets online and send their answers to the teacher. This is good for students (it motivates), for the teacher (it saves time) and for the environment (it saves paper) [4].

In addition, such interactive worksheets take full advantage of new technologies used in education: they can include sounds, videos, dragand-drop exercises, arrow connections, multiple choice and even oral exercises that students must perform with a microphone. 
Every person can use this platform to create their own interactive worksheets, or to use those provided by other teachers. There is a collection of thousands of interactive pages covering many languages and subjects. It's very simple to create your own interactive worksheets, you need to download your document and it will be converted into an image. Then you just need to draw squares on the sheet and enter the correct answers. There are also a few commands that you need to learn if you want to perform other exercises such as dragging, connecting with arrows, speaking exercises, etc. [4].

There are two ways of getting answers from your students: students open a worksheet, perform exercises and click "Done", then select "Send my teacher answers" and enter the teacher's email address (or secret access code), then you will receive an email and will be able to check the responses of all students in the inbox. There is no limit to the number of emails students can send to the teacher, but all their responses will be deleted in 30 days [4]. The other way is to create your own interactive workbooks and add your favourite worksheets (your own or shared for other teachers), then to register your students (they can also register with your secret key code) and to assign them workbooks. After that students can open workbooks with their username and password and perform exercises. The teacher can check their work at any time, assign homework and add comments or notes. Students may optionally register their email to receive notifications of homework and teacher comments. Interactive workbooks are easy to customize, allowing teachers to leave comments and save all your students' answers indefinitely.

Unfortunately, there are some limitations in interactive books, but for most teachers they are not a problem at all: teachers can create up to 10 interactive workbooks (120 pages each) and enrol up to 100 students. This means that you can save for free in your account $10 * 120 * 100=$ 120,000 answers from different students. If the teacher needs more students, more workbooks, or more personal letters, they can pay a premium subscription to increase these limits.

The teachers can insert their own worksheets and even sheets from other teachers (if they allow this option) to their own websites or blogs. Many worksheets can also be downloaded in pdf format (if the author has allowed this feature), that allow teachers to use them in offline mode.

Let's demonstrate one of many uses of interactive worksheets at language lessons:
- the teacher develops and provides students with access to an interactive worksheet (by link or by code);

- a copy of the worksheet is created for each student to receive the template;

- the student assigns his name to the template and performs tasks on its working field;

- at the end of the work, the student provides (by link) access to the received interactive sheet for both the teacher and classmates. Such a didactic opportunity allows you to implement information interaction in a digital educational environment, to support the practice of argumentation and discussion, formulation of wellgrounded remarks and comments.

Dynamism, versatility, accessibility, ease of use, the possibility of use as a training simulator, etc. are the main advantages of an interactive book. That's why teachers can diversify language lessons using them.

\section{Conclusion}

Thus, depending on the problem situation and the teacher's ability to simulate the educational space, work with interactive sheets can include a full cycle of educational activities from immersion in the topic and setting a task to evaluate work results. The main advantages of worksheets are: the ability to copy multiple times; discussion of works with subsequent editing of the content or answers; the speed of replacing information on an already created sheet; the possibility of filling at home.

Thanks to the unique features of the interactive book, such as animation, compactness, multidimensionality of information transfer, emotional impact on the reader's perception, teachers can successfully compete with online resources and television, involve students in active and educational reading. Creating an interactive book is a promising area of not only publishing, but teaching as it will open new horizons and develop in accordance with modern user needs.

Now, therefore, the proposed approach contributes to improving the quality of student language training, forming the practice of information communication and support of student practical creative activities, implementing the principles of the system-activity approach in teaching, individualization of the educational process. However, the teachers should improve their skills of using digital technologies, in particular, interactive worksheets.

\section{References}

1. Bikowski D., Casal J. E. Interactive Digital Textbooks and Engagement: A Learning Strategies 
Framework. Language Learning \& Technology, 2018. Vol. 22. No 1. P. 119-137.

2. Chou I. Reading for the purpose of responding to literature: EFL students' perceptions of ebooks. Computer Assisted Language Learning, 2016. Vol. 29 (1). P. 1-20.

3. Gu X., Wu B., Xu X. Design, development, and learning in e-Textbooks: What we learned and where we are going. Journal of Computers in Education, 2015. Vol. 2 (1). P. 25-41.

4. Liveworksheets platform website. URL: https://www.liveworksheets.com/

5. Бондаренко Я. Книжки, в которые играют, игры, которые читают: игровая деятельность как одно из направлений работы детской библиотеки. Світ дитячих бібліотек. URL : http://www.chl.kiev.ua/ UKR/magazin/Svit_n20/10.htm.

6. Вуль В. А. Электронные издания. СПб. : БХВПетербург, 2003. 560 с.

7. Городенко Л. М. Інтерактивна книга. Інформаційне суспільство, 2010. № 12. С. 16-19.

8. Еко У., Кар'єр Ж.-К. Не сподівайтеся позбутися книжок. Львів: Видавництво Старого Лева, 2015. $256 \mathrm{c}$.

9. Єфімова М. П. Видавництва дитячої книги в Україні : новітні видавничі технології. Теорія та практика дизайну. Мистецтвознавство. 2015. Вип. 7. С. 157-167.

10. Єфімова М. П. Інтерактивна дитяча книга в Україні: становлення та перспективи. Украӥнська культура: минуле, сучасне, шляхи розвитку : зб. наук. пр. : Записки рівненського державного гуманітарного університету. Рівне, 2014. Вип. 19. С. 259-263.

11. Женченко М. Дитяча література в електронному форматі: типологічна характеристика, бізнес-моделі. Вісн. Кн. Палати, 2016. № 5. С. $14-17$.

12. Коржик Н. А. Інтерактивна книга як сучасний видавничий продукт. Вісник Харківської державної академї культури. Серія : Соціальні комунікації. 2018. Вип. 53. С. 49-58.

13. Лисенко А. Особливості співіснування електронних та друкованих книжкових видань. Украйнський інформаџійний простір, 2011. № 20. С. 241-246.

14. Маркова В. А. Електронна книга : наукове поняття чи метафора? Бібліотекознавство. Документознавство. Інформологія. 2009. № 3. C. $69-74$.

15. Назаркевич М. А., Сторож О. В., Клюйник I. I. Особливості розроблення інтерактивних книг. Вісник Національного університету “Львівська політехніка". Інформачійні системи та мережі. 2015. № 832. С. 332-347.

16. Сучасні технології електронних мультимедійних видань : монографія / під ред. О. І. Пушкаря. Харків : ІНЖЕК, 2011. 296 с.

\section{References}

1. Bikowski D., Casal J. E. Interactive Digital Textbooks and Engagement: A Learning Strategies Framework. Language Learning \& Technology, 2018. Vol. 22. No 1. P. 119-137.

2. Chou I. Reading for the purpose of responding to literature: EFL students' perceptions of ebooks. Computer Assisted Language Learning, 2016. Vol. 29 (1). P. 1-20.

3. Gu X., Wu B., Xu X. Design, development, and learning in e-Textbooks: What we learned and where we are going. Journal of Computers in Education, 2015. Vol. 2 (1). P. 25-41.

4. Liveworksheets platform website. Available at: https://www.liveworksheets.com/

5. Bondarenko Ya. Books that are played, games that are read: game activities as one of the directions of the children library. The world of children libraries. Available at: http://www.chl.kiev.ua/ UKR/magazin/Svit_n20/10.htm.

6. Vul' V. A. Electronic piblications. SPb. : BHVPeterburg, 2003. $560 \mathrm{p}$.

7. Gorodenko L. M. Interactive books. Information society, 2010. No 12. P. 16-19.

8. Eco U., Karyer J. K. Don't expect to get rid of books. Lviv: Staryi Lev PH, 2015. 256 p.

9. Yefimova M. P. Children book publishing houses in Ukraine: the latest publishing technologies. Theory and practice of design. Art history.2015. Issue 7. P. 157-167.

10. Yefimova M. P. Interactive children book in Ukraine: formation and prospects. Ukrainian culture: past, present, ways of development: coll. sc. works: Zapy`sky` rivnens kogo derzhavnogo gumanitarnogo universy'tet., Rivne, 2014. No. 19. P. 259-263.

11. Zhenchenko M. Children's literature in electronic format: typological characteristics, business models. Bisnyk Knyzhkovoji Palaty, 2016. No 5. P. 14-17.

12. Korzhyk N. A. Interactive book as a modern publishing product. Bulletin of Kharkiv State Academy of Culture. Social communication. 2018. No. 53. P. 49-58.

13. Lysenko A. Features of the coexistence of electronic and printed books. Ukrainian information space, 2011. No 20. P. 241-246.

14. Markova V. A. E-book: a scientific concept or metaphor? Library science. Documentation. Informology. 2009. No 3. P. 69-74.

15. Nazarkevich M.A., Storozh O.V., Klyuynyk I.I. Features of the development of interactive books. Bulletin of the National University "Lviv Polytechnic". Information systems and networks. 2015. No 832. P. 332-347.

16. Modern technologies of electronic multi-media publications: monograph / ed. O.I. Pushkar. Kharkiv: INZHEK, 2011. 296 p.

Novikova Yevgeniya ${ }^{1}$, associate professor, $\mathrm{PhD}$, Department of Foreign Languages, 
tel. +38 095-829-73-72, vasilyok@ukr.net

${ }^{1}$ Kharkiv National Automobile and Highway University, 25, Yaroslava Mudrogo str., Kharkiv, 61002, Ukraine.

Использование Liveworksheets с целью разнообразить занятия по изучению языку

Аннотация. В статье раскрыто понятие «интерактивная книга». Представлень преимущества использования интерактивных книг при обучении языку. Показаны особенности создания собственных интерактивных рабочих тетрадей с помощью платформы Liveworksheets.

Ключевые слова: интерактивная книга, Liveworksheets, обучение языку, создание рабочей тетради.

Новикова Евгения Борисовна ${ }^{1}$, к.филол.н., доц. каф. иностранных языков, тел. 38 095-829-73-72, vasilyok@ukr.net

${ }^{1}$ Харьковский национальный автомобильнодорожный университет, 61002, Украина, г. Харьков, ул. Ярослава Мудрого, 25.

Застосування Liveworksheets для урізноманітнення занять із вивчення мови

Анотація. Проблема. 3 розвитком нових інформаційних технологій третього тисячоліття сформувалося нове покоління людей циифрової ери, які не уявляють своє життя без технологій та Інтернету. У контексті жорсткої конкуренції читання з комп'ютерними іграми постає проблема у створенні необхідного інструмента комунікації, який поєднує цчі два типи дозвілля. Таким продуктом є інтерактивна книга, яка ще не є всебічно вивченою. Мета. Мета статті - розкрити сутність та переваги використання інте- рактивних книг, зокрема робочих аркушів під час викладання мови. Методика. Поставлені в статті завдання зумовили застосування синхронно-описового методу з елементами порівняльного аналізу, методу моделювання, щчо сприяв комплексному вивченню платформи Liveworksheets. Результати. Розкрито сутність поняття «інтерактивна книга». Проаналізовано наявні платформи для створення таких продуктів. Визначено особливості створення власних інтерактивних книжок. Наведено приклади робочих зошитів на платформі Liveworksheets. Оригінальність. Всебічно розглянуто процес створення інтерактивних робочих зошитів при викладанні мови. З'ясовано особливості їхнього використання. Практична цінність. Завдяки унікальним особливостям інтерактивної книги, таким як анімація, компактність, багатовимірність передачі інформаџії, емочійний вплив на сприйняття читача, викладачі, щзо використовують їх, можуть успішно конкурувати з інтернет-ресурсами та телебаченням, залучати студентів до активного та навчального читання як в аудиторії, так і вдома.

Ключові слова: інтерактивна книга, Liveworksheets, вивчення мови, створення робочого зошита.

Новікова Свгенія Борисівна ${ }^{1}$, к.філол.н., доц. каф. іноземних мов, vasilyok@ukr.net, тел. +38 095-829-73-72,

${ }^{1}$ Харківський національний автомобільнодорожній університет, 61002, Україна, м. Харків, вул. Ярослава Мудрого, 25. 